\title{
Materials to the lichen biota of the hill in Folusz near Szubin (NW Poland)
}

\author{
*Edyta Adamska, **Adam Adamski \\ *Chair of Geobotany and Landscape Planning \\ **Museum of Natural History \\ Nicolaus Copernicus University, Faculty of Biology and Environmental Protection, \\ Lwowska 1, 87-100 Toruń, e-mail: adamska@umk.pl
}

\begin{abstract}
A total of 37 lichen species were identified during the first lichenological research conducted in 2014 on the Folusz hill, including 28 taxa of epiphytes, 10 epixylic lichens and 4 common species of epigeic lichens. Historical sources contain only data on the occurrence of 13 taxa of epigeic lichens. In total, the list of lichens occurring in this area includes 48 species. No characteristic species of xerothermic grasslands were recorded at present or in the past.
\end{abstract}

Key words: lichens, xerothermic grasslands, the dune hill, biota changes, biodiversity, Noteć river valley.

\section{Introduction}

Lichens occurring on xerothermic grasslands in Poland are significantly threatened. Epigeic xerothermic lichens occurring in the lowlands and uplands in Southern Poland are particularly endangered with extinction. Risk factors include mainly the exploitation of rock material and afforestation of grasslands (Cieśliński \& Czyżewska 1992).

Lichens occurring on xerothermic grasslands in Poland have been the subject of many studies; Southern Poland is the best explored part of Poland in this respect. In the northern part of Poland, xerothermic vegetation covers only a small area, and the largest concentration of this type of habitats is located in the area of the Lower Oder River, the Warta River and the Vistula River (Ceynowa-Giełdon 1994).

The occurrence of xerothermic lichens in Poland was described by many authors, e.g.: Ceynowa-Giełdon (1994, 2001), Ceynowa-Giełdon \& Glazik (1994), Cieśliński (1979, 1981), Glanc (1964), Wieczorek \& Schiefelbein (2014), and outside the borders of Poland by i.a. Otte and Ratzel (2004).
One of the most interesting sites of xerothermic vegetation in lowland Poland is a dune hill located in the vicinity of the Folusz village near the town of Szubin, due to its location among the extensive meadows instead in river valleys. Vegetation of this area represents a cold Stipa steppe (Kunz et al. 2014).

Vegetation of the Folusz hill has been frequently studied, and data on this subject can be found in papers by Banaszak et al. (2004), Ceynowa (1968), Krasicka-Korczyńska (2004), Wilkoń-Michalska \& Bohr (1960), in recent studies by Kunz et al. (2013), Kunz et al. (2014), Nienartowicz et al. (2014) and in unpublished materials of Wilkoń-Michalska.

The available information on the lichen biota from this area is very scanty, including both published and unpublished data. Only Ceynowa (1968) reports on a few common epigeic lichen species from the area of Folusz found in the course of her phytosociological studies. Another source of historical data on the occurrence of lichens are unpublished data coming from the notes made by Wilkon-Michalska in 1956, 1959 and 1964. Lichenological data provided by 
Nienartowicz et al. (2014) are consistent with those included in this paper.

The aim of this study was to collect data on the occurrence of lichens on the Folusz hill and to create the first list of species from this area, including historical data, both published and unpublished. This work focused on the occurrence of lichens on all available substrates, in particular epigeic species valuable for xerothermic grasslands.

\section{The study area}

The Folusz dune hill is situated at a distance of ca. $4 \mathrm{~km}$ from Szubin (the western part of the Kujawy-Pomerania province) in north-western Poland. A detailed description of the study area as well as a map of its location and land cover were presented in several previous studies (i.a. Kunz et al. 2013; Kunz et al. 2014; Nienartowicz et al. 2014: this issue of Ecological Questions). The Folusz hill is a sandy dune located in the middle of peat-bog meadows from the Molinietalia order in the Noteć ice-marginal valley (Korczyńska-Krasicka \& Rutkowski 2005). The wedge-shape dune with a length of $300 \mathrm{~m}$ and a width of $100 \mathrm{~m}$ covers ca. 3 ha (Wilkoń-Michalska \& Bohr 1960). As reported by Kunz et al. (2013), sand was extracted from the dune until the mid-1950s, and a road was dug through the highest part of the dune. Grasslands overgrown with Calamagrostis epigejos, Bromus inermis and Brachypodium pinnatum have been preserved between the trees on the Folusz hill, including steppe plant species. According to the aforementioned authors, rare, threatened and protected plant species still occur in the study area despite strong human impact.

\section{Methods}

Lichens were studied on the hill in Folusz at 12 sites on the 16th September, 2014. They were examined on all available substrates - the bark of trees, wood and sandy soil. Some of the species were identified in the field, other specimens were collected for further analysis in a laboratory. The collected material was deposited in the NCU herbarium in Torun (TRN). Species protected by law (Regulation 2014) were not collected.

Several identification keys were used during the taxonomic verification, including in particular the study by Smith et al. (2009).

To compile a list of lichen species from the Folusz area, both published (Ceynowa 1968) and unpublished data were used. The latter data were extracted from the notes made by Professor Jadwiga Wilkon-Michalska in 1956, 1959 and 1964. Names of lichen species were written down in the course of making the relevés. It was not possible to find the lichenological herbarium material from the previous re- search, and therefore data from unpublished and published sources could not be taxonomically verified. Some of the species were identified in a broader taxonomic approach (s.1.). Specimens from the genus Lepraria were classified as Lepraria sp.

The nomenclature of species follows mainly Diederich et al. (2014), except for taxa from the family of Teloschistaceae Zahlbr. (Arup et al. 2013) and the following species: Lecanora conizaeoides (Index Fungorum 2014) and Melanelixia glabratula (Arup \& Sandler Berlin 2011). The conservation status of species follows the Regulation from 2014, and threatened species categories in Poland are accepted after Cieśliński et al. (2006).

The following abbreviations were used on the list of lichen species: (1...12) - number of sites, Protected by law (Regulation 2014): $\S$ - partially protected species; Red List Categories: VU - Vulnerable, NT - Near Threatened, DD - Data Deficient (Cieśliński et al. 2006).

\section{Results}

A total of 48 lichen species were identified in the area of Folusz, including 37 species in the course of inventory conducted in 2014 (Fig. 1). Four lichen species are listed on the Red List of endangered lichens in Poland (Cieśliński et al. 2006). These species are included in the three threat categories: VU - Peltigera canina (reported only in historical unpublished materials) and Ramalina pollinaria, NT - Evernia prunastri and DD - Lecanora persimilis. Only two partially protected species (pursuant to the currently valid Regulation dated 2014) have been so far identified in the study area, i.e. Cladonia arbuscula (historical data) and Ramalina pollinaria.

Epiphytic lichens (28 taxa) dominated among the currently identified species; they occur on the following phorophytes: Acer platanoides, Betula pendula, Populus tremula, Pinus sylvestris, Padus serotina and Quercus robur. According to Nienartowicz et al. (2014), based on the data described in this study, the bark of more than 100 years old oak trees and birch trees (10-15 species, respectively) was most abundantly colonized by lichens. Hypocenomyce scalaris was the most frequent epiphytic lichen, found on 11 out of the 12 analysed sites. Thalli of this species were found on wood and on most examined phorophytes. Lepraria $\mathrm{sp}$. also occurred in large numbers - at 9 sites. Noteworthy is the abundant occurrence of nitrophilous and coniophilous species - Xanthoria parietina (9 sites), Physcia tenella (8) and Polycauliona polycarpa (6). No data were found in the historical materials on the occurrence of epiphytic lichens in Folusz.

At present, also the occurrence of lichens growing on the wood was analysed. Ten epixylic lichen species were identified, including four species growing only on wood: 


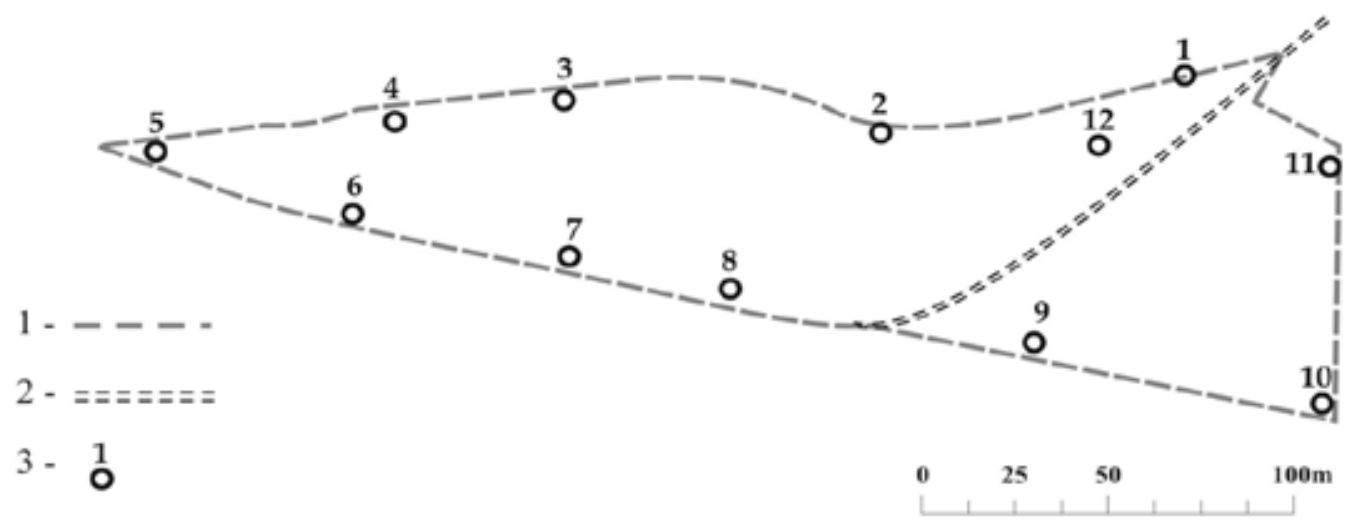

Figure 1. Distribution of sites in Folusz (explanations of the numbers included in the text); 1 - border of studies; 2- road; 3 - No. of sites

Cladonia digitata, C. macilenta, Placynthiella dasaea, Trapeliopsis flexuosa. Similarly to the group of epiphytes, also epixylic lichens were not reported in the historical material related to Folusz.

Only four epigeic lichen species were currently identified in the study area: Cladonia cornuta, C. fimbriata $C$. furcata, and Trapeliopsis granulosa. These species were found mainly at site no. 10 (N52 58.672 E17 42.440), growing in the sun on sandy soil. As it appears from the historical, both published and unpublished data, 13 lichen taxa grew on the soil at the site in Folusz. In addition to the species from the genus Cladonia, also two taxa from the genus Peltigera were found.

The list of sites plotted in Figure 1:

1 - compact canopy of Quercus robur with Betula pendula (N52 58.730 E17 42.392)

2 - compact canopy of Quercus robur with Betula pendula (N52 58.731 E17 42.329)

3 - compact canopy of Quercus robur with Betula pendula (N52 58.731 E17 42.246)

4 - pine plantation (N52 58.724 E17 42.204)

5 - compact canopy of Quercus robur with Betula pendula (N52 58.719 E17 42.137)

6 - pine plantation (N52 58.706 E17 42.192)

7 - pine plantation (N52 58.701 E17 42.249)

8 - pine plantation (N52 58.696 E17 42.290)

9 - pine plantation (N52 58.682 E17 42.366)

10 - bare sand (N52 58.672 E17 42.440)

11 - pine plantation (N52 58.718 E17 42.445)

12 - birch plantation (N52 58.719 E17 42.386)

List of species:

1. Athallia holocarpa (Hoffm.) Arup, Frödén \& Søchting s.1. [syn. Caloplaca holocarpa (Hoffm.) A. E. Wade] 2 localities $(1,2)$; on the bark of Populus tremula.
2. Buellia punctata (Hoffm.) A. Massal. - 5 localities (1, 5-8); on the bark of Populus tremula and Quercus robur, on the wood.

3. Candelaria pacifica M. Westb. \& Arup - 3 localities (1, $6,12)$; on the bark of Betula pendula, Padus serotina and Quercus robur.

4. Candelariella efflorescens R. C. Harris \& W. R. Buck1 locality (1); on the bark of Quercus robur.

5. Cladonia arbuscula (Wallr.) Flot. [on the soil, as Cladonia sylvestris (Wilkon-Michalska1964), unpublished data]; .

6. Cladonia chlorophaea (Sommerf.) Spreng. [on the soil, (Ceynowa 1968)].

7. Cladonia coniocraea (Flörke) Spreng. -3 localities (2, $6,12)$; on the bark of Betula pendula and on the wood.

8. Cladonia cornuta (L.) Hoffm. - 1 locality (10); on the soil [and acc. Ceynowa 1968).

9. Cladonia digitata (L.) Hoffm. - 1 locality (6); on the wood.

10. Cladonia fimbriata (L.) Fr. - 1 locality (10); on the soil; [and acc. (Wilkon'- Michalska1956) unpublished data].

11. Cladonia floerkeana (Fr.) Flörke [on the soil, (Wilkoń-Michalska1964) unpublished data].

12. Cladonia foliacea (Huds.) Willd. [on the soil, as Cladonia foliacea var. alcicornis (Wilkoń-Michalska1956, 1964), unpublished data and Ceynowa (1968)].

13. Cladonia furcata (Huds.) Schrad. subsp. furcata - 1 locality (10); on the soil, [and acc. (Ceynowa 1968)].

14. Cladonia glauca Flörke [on the soil, (Wilkoń-Michalska1956) unpublished data].

15. Cladonia gracilis (L.) Willd. [on the soil, (Wilkoń-Michalska1964) unpublished data].

16. Cladonia macilenta Hoffm. - 2 localities $(6,8)$; on the wood.

17. Cladonia pyxidata (L.) Hoffm. s.l. [on the soil, (Wilkoń-Michalska1964) unpublished data. 
18. Cladonia sp. [on the soil, (Wilkon'-Michalska1959) unpublished data].

19. Cladonia verticillata (Hoffm.) Schaer. [on the soil, (Wilkoń-Michalska 1964) unpublished data].

20. Evernia prunastri (L.) Ach. - 3 localities (1, 2, 10); on the bark of Betula pendula, Padus serotina and Quercus robur; NT.

21. Hypocenomyce scalaris (Ach.) M. Choisy - 11 localities (1-8, 10-12); on the bark of Acer platanoides, Betula pendula, Pinus sylvestris and Quercus robur, and on the wood.

22. Hypogymnia physodes (L.) Nyl. - 4 localities (2, 4, 10, 12); on the bark of Betula pendula, Pinus sylvestris and Quercus robur.

23. Lecanora conizaeoides Nyl. ex Cromb - 5 localities (4-6, 9, 10); on the bark of Pinus sylvestris.

24. Lecanora carpinea (L.) Vain. - 2 localities $(2,5)$; on the bark of Quercus robur.

25. Lecanora chlarotera Nyl. - 3 localities $(2,3,7)$; on the bark of Betula pendula, Populus tremula and Quercus robur.

26. Lecanora dispersa (Pers.) Sommerf. - 3 localities (2, $3,5)$; on the bark of Quercus robur.

27. Lecanora hagenii (Ach.) Ach. - 2 localities (2, 3); on the bark of Betula pendula, Populus tremula and Quercus robur.

28. Lecanora persimilis (Th. Fr.) Nyl. - 1 locality (2); on the bark of Populus tremula and Quercus robur; DD.

29. Lecidella elaeochroma (Ach.) M. Choisy - 1 locality (3); on the bark of Populus tremula.

30. Lepraria sp. - 9 localities (1-6, 10-12); on the bark of Betula pendula, Pinus sylvestris and on the wood.

31. Melanelixia glabratula (Lamy) Sandler \& Arup [syn. M. fuliginosa (Fr. ex Duby) O. Blancoet all. subsp. glabratula (Lamy) J. R. Laundon] - 1 locality (7); on the bark of Quercus robur.

32. Melanohalea exasperatula (Nyl.) O. Blancoet all. 1 locality (10); on the bark of Betula pendula.

33. Parmelia sulcata Taylor - 6 localities (1, 2, 5, 10-12); on the bark of Acer platanoides, Betula pendula, Populus tremula, Padus serotina and Quercus robur.

34. Peltigera canina (L.) Willd. [on the soil, (Wilkoń-Michalska1959) unpublished data]; VU.

35. Peltigera rufescens (Weiss) Humb. [on the soil, (Wilkoń-Michalska1959) unpublished data].

36. Phaeophyscia orbicularis (Neck.) Moberg - 3 localities $(2,3,7)$; on the bark of Populus tremula and Quercus robur.

37. Phlyctis argena (Spreng.) Flot. - 1 locality (4); on the bark of Acer platanoides.

38. Physcia adscendens H. Olivier - 2 localities (3, 5); on the bark of Populus tremula and Pinus sylvestris.
39. Physcia tenella (Scop.) DC. -8 localities (1-3, 5-7, 10, 11); on the bark of Acer platanoides, Betula pendula, Padus serotina and Quercus robur.

40. Placynthiella dasaea (Stirt.) Tønsberg - 1 locality (10); on the wood.

41. Placynthiella icmalea (Ach.) Coppins \& P. James 3 localities $(5,6,8)$; on the wood.

42. Polycauliona candelaria (L.) Frödén, Arup \& Søchting [syn. Xanthoria candelaria (L.) Th. Fr. ] - 2 localities $(1,10)$; on the bark of Acer platanoides and Betula pendula.

43. Polycauliona polycarpa (Hoffm.) Frödén, Arup \& Søchting [syn. Xanthoria polycarpa (Hoffm.) Rieber] - 6 localities $(2,4-6,10,11)$; on the bark of Acer platanoides, Betula pendula, Pinus sylvestris, Populus tremula, Padus serotina and Quercus robur.

44. Ramalina pollinaria (Westr.) Ach. - 1 locality (11); on the bark of Quercus robur; §; VU.

45. Scoliciosporum chlorococcum (Stenh.) Vězda - 6 localities (1-3, 10-12); on the bark of Acer platanoides, Betula pendula, Populus tremula, Padus serotina and Quercus robur.

46. Trapeliopsis flexuosa (Fr.) Coppins \& P. James - 2 localities $(5,8)$; on the wood.

47. Trapeliopsis granulosa (Hoffm.) Lumbsch - 3 localities $(5,8,10)$; on the soil and wood.

48. Xanthoria parietina (L.) Th. Fr. - 9 localities (1-7, 11, 12); on the bark of Acer platanoides, Betula pendula, Populus tremula, Padus serotina and Quercus robur.

\section{Discussion and conclusions}

According to Fałtynowicz (1992) and Ceynowa-Giełdon (1994), the following lichen species characteristic of xerothermic grasslands occur in Western Pomerania: Bacidia bagliettoana (A. Massal. \& De Not.) Jatta, Cladonia furcata subsp. subrangiformis (Sandst.) Abbayes, Cladonia symphycarpia (Flörke) Fr., Endocarpon pusillum Hedw., Fulgensia fulgens (Sw.) Elenkin, Placidium squamulosum (Ach.) Breuss, Psora decipiens (Hedw.) Hoffm., Toninia sedifolia (Scop.) Timdal.

Nevertheless, no characteristic lichen species of xerothermic grasslands were found on the Folusz hill, neither in the past or at present. Historical data refer only to the occurrence of epigeic lichens from the genus Cladonia and Peltigera. At present, also other ecological groups were analysed, including epiphytic and epixylic lichens.

Lack of data on the occurrence of epigeic species characteristic of xerothermic grasslands probably results from the lack of lichenological studies in the previous research periods. Thus, it is possible that at the time when xerothermic grasslands were well-developed in the study area, species of epigeic xerothermic lichens occurred there too. 
Epigeic lichen species withdraw because of the vegetation encroachment on the habitats, which results in changes in the light and trophic conditions.

Important factors affecting the changes in the habitat conditions in Folusz include sand exploitation in this area. In addition, as a consequence of pine cultivation, the vegetation cover in the study area has become uniform (Kunz et al. 2013). Such measures affect both epigeic lichens in xerothermic grasslands and at other sites, e.g. on the Zadroże Dune near the city of Torun (Adamska 2010; Nienartowicz et al. 2010).

Noteworthy is the spread of epiphytic coniophilous and nitrophilous lichen species in Folusz (cf. Nienartowicz et al. 2014). This may prove the ongoing eutrophication process in the habitat, which affects the preservation of conditions for xerothermic lichen species. Similar habitat changes, such as overgrowing of grasslands, an increase in the trophic status, habitat fragmentation, which negatively affect the preservation of xerothermic grasslands, and consequently the lichen biota, were also described by Wieczorek and Schiefelbein (2014).

\section{Acknowledgements}

The authors are grateful to Professor Andrzej Nienartowicz for his interest in the lichenological studies in the area of Folusz. We thank Mr Dariusz Kamiński for drawing the distribution map of sites. We express our sincere gratitude to an anonymous Reviewer for valuable remarks and suggestions.

\section{References}

Adamska E., 2010, Biota of lichens on the Zadroże Dune and its immediate surroundings, Ecological Questions 12: $51-58$

Arup U. \& Sandler Berlin E., 2011, A taxonomic study of Melanelixia fuliginosa in Europe, Lichenologist 43(2): 89-97.

Arup U., Søchting U. \& Frödén P., 2013, A new taxonomy of the family Teloschistaceae, Nord. J. Bot. 31: 16-83.

Banaszak J., Ratyńska H. \& Banaszak W., 2004, Proponowany rezerwat "Folusz" pod Szubinem jako ostoja termofilnej szaty roślinnej i fauny żądłówek (Hymenoptera: Aculeata: Apoidea, Scolioidea) [Proposed „Folusz" nature near Szubin (in Poland) as refuge of thermophilous plant cover and the fauna of the superfamilies Apoidea and Scolioidea (Hymenoptera, Aculeata)], Badania Fizjograficzne nad Polską Zachodnią, Seria C, Zoologia 50: 101-132.

Ceynowa M., 1968, Zbiorowiska roślinności kserotermicznej nad dolną Wisłą [Xerotherme Pflanzengesellschaf- ten an der intern Wisła], Studia Soc. Torunensis, Toruń - Polonia, Sec. D (Botanica) vol. VIII, Nr 4, TNT, Torun.

Ceynowa-Giełdon M., 2001, Kalcyfilne porosty naziemne na Kujawach [Calciphilous terricolous lichens in $\mathrm{Ku}-$ jawy], Wydawnictwo UMK, Torun.

Ceynowa-Giełdon M. \& Glazik N., 1994, Rzadkie porosty kserokontynentalne na obszarze dolnej Wisły [Rare xerocontinental lichens in the Lower Vistula region], Fragmenta Floristica et Geobotanica Ser. Polonica 1: 41-47.

Ceynowa-Giełdon M., Adamska E. \& Kamiński D., 2004, Porosty w dolinie dolnej Wisły i na obszarze przemysłowym Kujaw [Lichens in the Lower Vistula Valley and In the industrial area of the Kujawy region], [in:] E. Krasicka-Korczyńska, M. Korczyński (eds.), Wycieczki geobotaniczne. Region kujawsko-pomorski, [Geobotanical excursions. The Kujawy-Pomerania Region], Bydgoszcz-Torun: 13-22.

Cieśliński S., 1979, Udział oraz rola diagnostyczna porostów naziemnych w zbiorowiskach roślin naczyniowych Wyżyny Kieleco-Sandomierskiej i jej pobrzeży [Contribution and diagnostics significance of terricolous lichens in vascular-plant communities of the Kieleco-Sandomierska Upland and its periphery], Wydawnictwo WSP, Kielce.

Cieśliński S., 1981, Nowe i bardziej interesujące gatunki porostów na Wyżynie Kielecko-Sandomierskiej i jej pobrzeżach [New and more interesting species of tericolous lichens in the area of the Kielecko-Sandomierska Upland and its periphery], Fragmenta Floristica et Geobotanica 27(3): 527-539.

Cieśliński S. \& Czyżewska K., 1992, Problemy zagrożenia porostów w Polsce [Problems of threatened lichenized fungi in Poland], Wiadomosci Botaniczne 36(1-2): 5-17.

Cieśliński S., Czyżewska K. \& Fabiszewski J., 2006, Red list of the lichens in Poland, [in:] Z. Mirek, K. Zarzycki, W. Wojewoda, Z. Szeląg (eds.), Red list of plants and fungi in Poland, W. Szafer Institute of Botany, Polish Academy of Sciences, Kraków: 71-89.

Diederich P., Ertz D., Stapper N., Sérusiaux E., Van den Broeck D., van den Boom P. \& Ries C., 2014, The lichens and lichenicolous fungi of Belgium, Luxembourg and northern France, URL: http://www.lichenology.info [Assessed 17.10.2014].

Faltynowicz W., 1992, The lichens of Western Pomerania - an ecogeographical study, Polish Botanical Studies 4: $1-183$.

Glanc K., 1964, Lecidea decipiens (Ehrh.) Ach. i inne interesujące gatunki porostów w murawach kserotermicznych północno-zachodniej Polski, Fragmenta Floristica et Geobotanica 10(2): 263-267. 
Index Fungorum, 2014, http://www.indexfungorum.org/ names/names.asp [Accessed 16.10.2014]

Krasicka-Korczyńska E., 2004, Folusz koło Szubina ścieżka przyrodnicza [Folusz near Szubin: a nature path], BIS-MEDIUM, Polskie Towarzystwo Botaniczne, Warszawa.

Krasicka-Korczyńska E. \& Rutkowski L., 2005, Biodiversity of Molinia Meadows in Folusz near Szubin, [in:] K. Czyżewska, J. Hereźniak (eds) Biodiversity in Relation to Vegetation Zones in Europe, University of Łódź Publishing House, Łódź: 97-107.

Kunz M., Nienartowicz A., Kamiński D. \& Deptuła M., 2013, Zastosowanie technologii GIS do oceny zmian występowania roślinności kserotermicznej na stanowisku w Foluszu koło Szubina w 1959 i 2012 roku [Application of GIS technology in the assassment of changes in xerothermic vegetation at the Folusz site near Szubin in 1959 and 2012], [in:] M. Kunz, A. Nienartowicz (eds) Systemy informacji geograficznej w zarządzaniu obszarami chronionymi - od teorii do praktyki [Geographical information systems in the management of protected areas - from theory to practice], Tuchola - Toruń: 97-107.

Kunz M., Nienartowicz A., Kamiński D. \& Deptuła M., 2014, Stanowisko Folusz - analiza zmian krajobrazowych [Position of the Folusz - analysis of changes in the landscape] Kalejdoskop GIS, Esri Polska, Warszawa 3: 90-91.

Nienartowicz A., Kamiński D., Kunz M., Deptuła M. \& Adamska E., 2014, Changes in the plant cover of the dune hill in Folusz near Szubin (NW Poland) between 1959 and 2013: the problem of preservation of xerothermic grasslands in the agricultural landscape, Ecological Questions 20 (this issue).
Nienartowicz A., Kunz M., Adamska E., Boinska U., Deptuła M., Gugnacka-Fiedor W., Kamiński D. \& Rutkowski L., 2010, Relief and changes in the vegetation cover and the flora of the Zadroże Dune near the city of Torun: Comparison of the conditions in 1948 and 2009, Ecological Questions 12: 17-49.

Otte V. \& Rätzel S., 2004, Kommentiertes Verzeichnis der Flechten und flechtenbewohnenden Pilze Brandenburgs, Deutzchland, Feddes Repertorium 115(1-2): 135-154.

Rozporządzenie Ministra Środowiska z dnia 9 października 2014 r. w sprawie ochrony gatunkowej grzybów Dz. U. poz. 1408 [Regulation of the Minister of Environment dated November 9, 2014 legally protected fungi. Dz.U. (Journal of Laws) item 1408], Warszawa. Smith C. W., Aptroot A., Coppins B. J., Fletcher A., Gilbert O. L., James P. W. \& Wolseley P. A., 2009, The lichens of Great Britain and Ireland, British Lichen Society, London.

Wieczorek A. \& Schiefelbein U., 2014, Lichens of xerothermic grasslands in Western Pomerania (Poland), Plant Diversity and Evolution 130(3-4): 295-302.

Wilkoń-Michalska J., Bohr R., 1960, Stanowisko lnu trwałego (Linum perenne L.) w Foluszu koło Szubina [Ein Fundort von Linum perenne L. in Folusz bei Szubin], Fragmenta Floristica et Geobotanica VI(3): 239-243. 